\title{
PENGEMBANGAN PANDUAN PELATIHAN EFIKASI DIRI DALAM HUBUNGAN PERTEMANAN MELALUI STRATEGI EXPERIENTIAL LEARNING BAGI SISWA SMP
}

\author{
Layli Novita Rachmawati, Nur Hidayah \\ Bimbingan dan Konseling-Fakultas Ilmu Pendidikan-Universitas Negeri Malang-Jl.Semarang No. 5 Malang \\ E-mail: vittavetty@ymail.com
}

\begin{abstract}
The research aims to develop self-efficacy training guides in friendship through experiential learning strategies for junior high school students. This training guide is printed teaching materials containing material, step training, and the evaluation.This study used a model of Borg and Gall (1983) descriptive development which did in 3 step; planning, developmental product, and trial of the product. Based on the results of data analysis from expert assessment and potential users as well as revisions that are made in accordance with the advice and input to the product, it can be concluded that the guidelines of this training meets the acceptance criteria in theory and practice well and effectively proven in increasing students' self-efficacy in relationship friendship. Suggestions for the counselor is using the guide as a media of personal-social guidance services for the student especially to improving self-efficacy in friendship. Researchers further, the format of assesment by experts and potential users need to considered details because the judge or scoring of each expert and thepotential users is not same. Moreover, the design and the content guidelines need to be considered in details too, so not much improvement.
\end{abstract}

Keywords: guideline development; self-efficacy; friendship; experiential learning

\begin{abstract}
Abstrak: Penelitian ini bertujuan untuk menghasilkan panduan pelatihan efikasi diri dalam hubungan pertemanan melalui strategi experiential learning bagi siswa SMP. Panduan pelatihan ini adalah bahan ajar berbasis buku cetak yang berisi materi, langkah kegiatan pelatihan, serta evaluasi. Prosedur penelitian dan pengembangan ini mengadaptasi pengembangan oleh Borg and Gall (1983) yang dilakukan dalam 3 tahapan yaitu, (1) perencanaan pengembangan produk, (2) pengembangan produk, dan (3) uji coba produk. Berdasarkan hasil analisis data penilaian ahli dan calon pengguna serta revisi-revisi yang dilakukan sesuai dengan saran dan masukan terhadap produk ini, dapat disimpulkan bahwa panduan pelatihan ini memenuhi kriteria keberterimaan secara teoritik dan praktik dengan baik dan terbukti efektif dalam meningkatkan efikasi diri siswa di dalam hubungan pertemanan sebaya. Saran bagi konselor yaitu menggunakan panduan sebagai media dalam layanan bimbingan pribadisosial kepada siswa khususnya dalam meningkatkan efikasi diri di dalam hubungan pertemanan. Peneliti selanjutnya, format penilaian oleh ahli dan calon pengguna dapat diperhatikan secara rinci karena penilaian isi/content produk oleh masing-masing ahli maupun pengguna tidaklah sama. Selain itu, tampilan serta content panduan juga perlu diperhatikan secara rinci sehingga tidak banyak perbaikan.
\end{abstract}

Kata Kunci: pengembangan panduan; efikasi diri; hubungan pertemanan; experiential learning 
Siswa pada jenjang sekolah menengah pertama termasuk dalam usia remaja awal. Pada masa ini siswa mulai mencoba bertingkah laku baru dan mencari identitas diri. Proses pergaulan dan pertemanan sebaya secara berkelompok juga menjadi ciri khas dalam masa ini. Aspek perkembangan hubungan sosial sangat berkembang pesat pada masa remaja awal, oleh karenanya hubungan sosial dalam pertemanan sebaya menjadi salah satu tugas perkembangan penting yang harus dipenuhi siswa. Santoso (2009) menyatakan salah satu kompetensi dasar yang harus dimiliki dan dipenuhi oleh siswa sekolah menengah pertama adalah perkembangan pribadi, kesadaran tanggung jawab sosial dan kematangan hubungan sosial dengan teman sebaya.

Hubungan pertemanan yang dimaksudkan adalah kemampuan siswa dalam melakukan hubungan atau interaksi sosial dengan teman sebaya secara baik dan penuh keyakinan. Siswa mulai berusaha memahami dirinya, meyakini segala potensi yang ia miliki, menerima orang lain (teman sebaya), memikirkan bagaimana ia akan memulai berinteraksi di lingkungan dan situasi yang baru, dengan siapa ia akan bergaul dan bagaimana orang lain (teman sebaya) bisa menerimanya. Namun pada proses ini, tidak jarang siswa cenderung mengalami kesulitan dalam berinteraksi sosial di lingkungan dan situasi yang baru, merasa minder dan tidak yakin untuk memulai berkomunikasi dengan teman, memilih-milih teman bergaul bahkan membentuk kelompok yang sesuai dengan keadaan diri. Adanya perilaku-perilaku tersebut menunjukkan rendahnya efikasi diri siswa dalam hubungan sosial.

Efikasi Diri (Self Efficacy) adalah keyakinan sejauh mana individu memperkirakan kemampuan dirinya dalam melaksanakan tugas atau melakukan suatu tugas yang diperlukan untuk mencapai suatu hasil tertentu. Menurut Bandura (1997), efikasi diri (Self Efficacy) adalah penilaian seseorang tentang kemampuannya sendiri untuk menjalankan perilaku tertentu atau mencapai tujuan tertentu. Efikasi diri (Self Efficacy) merupakan hal yang sangat penting dalam pertumbuhan dan perkembangan individu, termasuk pada aspek perkembangan sosial.

Self efficacy yang sangat berhubungan dengan hubungan interpersonal disebut dengan social self efficacy. Smith dan Betz (dalam Satici, Kayisa \& Akin: 2013) mendefinisikan social self efficacy sebagai "an individual's confidence his/her ability to engage in the social interactional task necessary to initiate and maintain interpersonal relationships". Gecas (dalam Satici, Kayisa, Akin: 2013) menyatakan bahwa individu dengan social self efficacy yang baik terampil dalam memulai kontak sosial dan mengembangkan hubungan pertemanan dan persahabatan yang baru. Dengan demikian efikasi diri sosial atau social self-efficacy merupakan keyakinan seseorang tentang kemampuannnya untuk memulai dan mempertahankan hubungan sosial dan mengelola konflik dengan orang lain. Social self-efficacy penting tidak hanya dalam hubungan interpersonal sehingga seseorang dapat menjalin hubungan sosial yang efektif dengan orang lain, tetapi berpengaruh penting terhadap penyesuaian psikologis dan kesehatan mental, sehingga efikasi diri yang baik diperlukan oleh individu dalam melakukan hubungan pertemanan dengan individu lain.

Pada proses hubungan pertemanan yang baik dan ideal, efikasi diri memegang peran penting dalam diri setiap siswa untuk mampu mencapai hubungan pertemanan yang diidamkan. Efikasi diri membantu siswa untuk memahami dan meyakini kemampuan dirinya dalam keadaan baik untuk mencapai tujuannya dalam mengembangkan diri pada hubungan sosial pertemanan sebaya secara optimal. Siswa dengan efikasi diri yang baik mampu meyakini kemampuan dalam dirinya, menyesuaikan dirinya dalam lingkungan dan situasi baru dan dikembangkan dalam bentuk hubungan pertemanan yang baik dan ideal.

Tetapi kenyataan yang sering dijumpai adalah keadaan pribadi siswa yang tidak berkembang, tidak yakin akan kemampuannya dan rapuh. Perkembangan yang tidak optimal itu menjadi hambatan dalam memenuhi tugas perkembangan yaitu kematangan dalam hubungan pertemanan sebaya. Begitu pula yang terjadi di lingkungan sekolah menengah pertama, masih banyak dijumpai remaja mengalami kesulitan dalam berinteraksi sosial di lingkungan baru sebagai akibat rendahnya efikasi diri dalam diri remaja. Beberapa remaja yang mengalami hal tersebut akan memperlihatkan perilaku-perilaku yang mencerminkan kegagalan dalam mengembangkan potensi hubungan pertemanan.

Studi pendahuluan dilakukan pada salah satu SMP di kota Malang melalui kegiatan observasi dan wawancara dengan konselor sekolah terkait dengan permasalahan tersebut. Dari hasil observasi dan wawancara, didapatkan hasil bahwa permasalahan krisis keyakinan diri/kepercayaan diri siswa di dalam hubungan pertemanan sebaya juga menjadi permasalahan yang pokok dan sering ditemui di sekolah tersebut. 
Perilaku yang dimunculkan siswa di sekolah tersebut, seperti: (1) siswa merasa minder dan ragu untuk berteman dengan siswa lainnya; (2) siswa menutup diri dan menjadi pendiam di kelas; (3) siswa tidak menyelesaikan konflik dengan teman dengan baik; (4) siswa cenderung memilih-milih teman dalam bergaul; dan (5) siswa membentuk kelompok-kelompok pertemanan. Berbagai perilaku yang dimunculkan terkait rendahnnya efikasi diri oleh para siswa tersebut karena ketidakyakinan siswa akan kemampuan yang dimiliki untuk dikembangkan dalam hubungan sosialnya dengan teman sebaya. Adanya permasalahan yang diakibatkan rendahnya efikasi diri tersebut membuat para siswa merasa kesulitan dalam mengembangkan diri di dalam lingkungan sekolah.

Permasalahan rendahnya efikasi diri tidak bisa dibiarkan karena akan berpengaruh terhadap aspek yang lain. Oleh karena itu diperlukan suatu cara dan upaya kreatif agar siswa dapat mengarahkan dirinya menjadi individu yang memiliki keyakinan bahwa dirinya mampu menyelesaikan semua tugasnya dengan baik khususnya dalam tugas hubungan sosial pertemanan sebaya. Sekiranya pemahaman tentang efikasi diri dalam hubungan pertemanan tidak hanya cukup dengan cara diajarkan namun juga dipraktikkan melalui kegiatan-kegiatan yang bersifat kelompok maupun individu. Oleh karena itu, peneliti mencoba mengembangkan sebuah panduan pelatihan efikasi diri dalam hubungan pertemanan untuk meningkatkan kemampuan atau keyakinan diri siswa dalam mengembangkan potensinya dalam hubungan pertemanan.

Pelatihan efikasi diri dalam pertemanan dapat diberikan melalui strategi layanan bimbingan, khususnya layanan bimbingan pribadi dan sosial. Layanan bimbingan yang diberikan disini adalah layanan bimbingan kelompok melalui strategi pembelajaran Experiential Learning. Experiential Learning merupakan sebuah model holistik dari proses pembelajaran dimana manusia belajar, tumbuh dan berkembang. Kolb (1984) menggunakan istilah Experiential sebagai penekanan bahwa model pembelajarannya lebih didasarkan pada refleksi diri dari pengalaman daripada menguji tentang pengetahuan. Dengan pelatihan efikasi diri dalam pertemanan melalui strategi Experiential Learning (EL), keyakinan diri siswa dalam pertemanan dapat dikem-bangkan melalui pengalaman belajar.

Beberapa penelitian yang menggunakan pendekatan EL diantaranya yaitu Sayekti (2012) menyebutkan bahwa pelatihan efikasi diri melalui metode EL telah digunakan dan dikembangkan serta terbukti telah memenuhi aspek keberterimaan oleh ahli dan calon pengguna untuk membantu siswa dalam pelatihan efikasi diri untuk meningkatkan motivasi berprestasi. Hasil penelitian lain yang menggunakan pendekatan EL yaitu penelitian oleh Utami (2015), mengenai pengembangan panduan pelatihan coping self talk dengan model EL bagi siswa SMK. Penelitian ini terbukti telah memenuhi aspek keberterimaan dan terbukti efektif dalam meningkatkan coping self talk siswa SMK dalam melakukan praktikum.

Purwaningrum (2013) menggunakan metode penelitian tindakan kelas mengenai penerapan model EL dalam internalisasi mind skill bagi mahasiswa Bimbingan dan Konseling. Penelitian ini membuktikan bahwa pembelajaran melalui pengalaman dapat meningkatkan kemampuan mahasiswa calon konselor dalam menginternaliasi mind skilldi dalam kemampuan dan keterampilan konseling mereka. Penelitian Azmi (2014) membuktikan bahwa pengembangan panduan pelatihan mind skills dalam konseling menggunakan strategi EL memenuhi aspek keberterimaan oleh ahli dan calon pengguna. Berdasarkan beberapa penelitian yang telah dilakukan terkait dengan metode EL, dapat disimpulkan bahwa model EL dapat digunakan untuk meningkatkan perilaku dan keyakinan positif pada individu atau siswa. Dengan hasil penelitian terdahulu, peneliti memutuskan menggunakan strategi EL dalam pemberian pelatihan efikasi diri siswa dalam hubungan pertemanan. Pada pelaksanaannya diperlukan suatu panduan yang dapat membantu konselor dalam memandu atau memfasilitasi kegiatan bimbingan ini.

Penelitian dan pengembangan ini bertujuan untuk menghasilkan produk berupa panduan pelatihan efikasi diri siswa SMP dalam hubungan pertemanan melalui strategi experiential learning sehingga dapat digunakan konsleor sebagai media dalam memberikan layanan bimbingan pribadi-sosial kepada siswa khususnya dalam meningkatkan keyakinan diri (self efficacy) dalam hubungan pertemanan sebaya. Produk disesuaikan dengan perkembangan usia dan pemahaman siswa, bahasa yang digunakan dibuat sederhana, materi yang disajikan sesuai dengan keadaan yang biasanya dialami oleh siswa, dilengkapi dengan metode yang melibatkan siswa secara aktif didalamnya seperti permainan peran, refleksi diri dan diskusi kasus, desain produk disajikan dengan warna yang menarik disertai dengan kata mutiara di setiap topik bahasan sebagai motivasi siswa. 


\section{Tahap I \\ Perencanaan Pengembangan}

1. Menentukan masalah penelitian,

2. Mengkaji literatur

3. Analisis kebutuhan

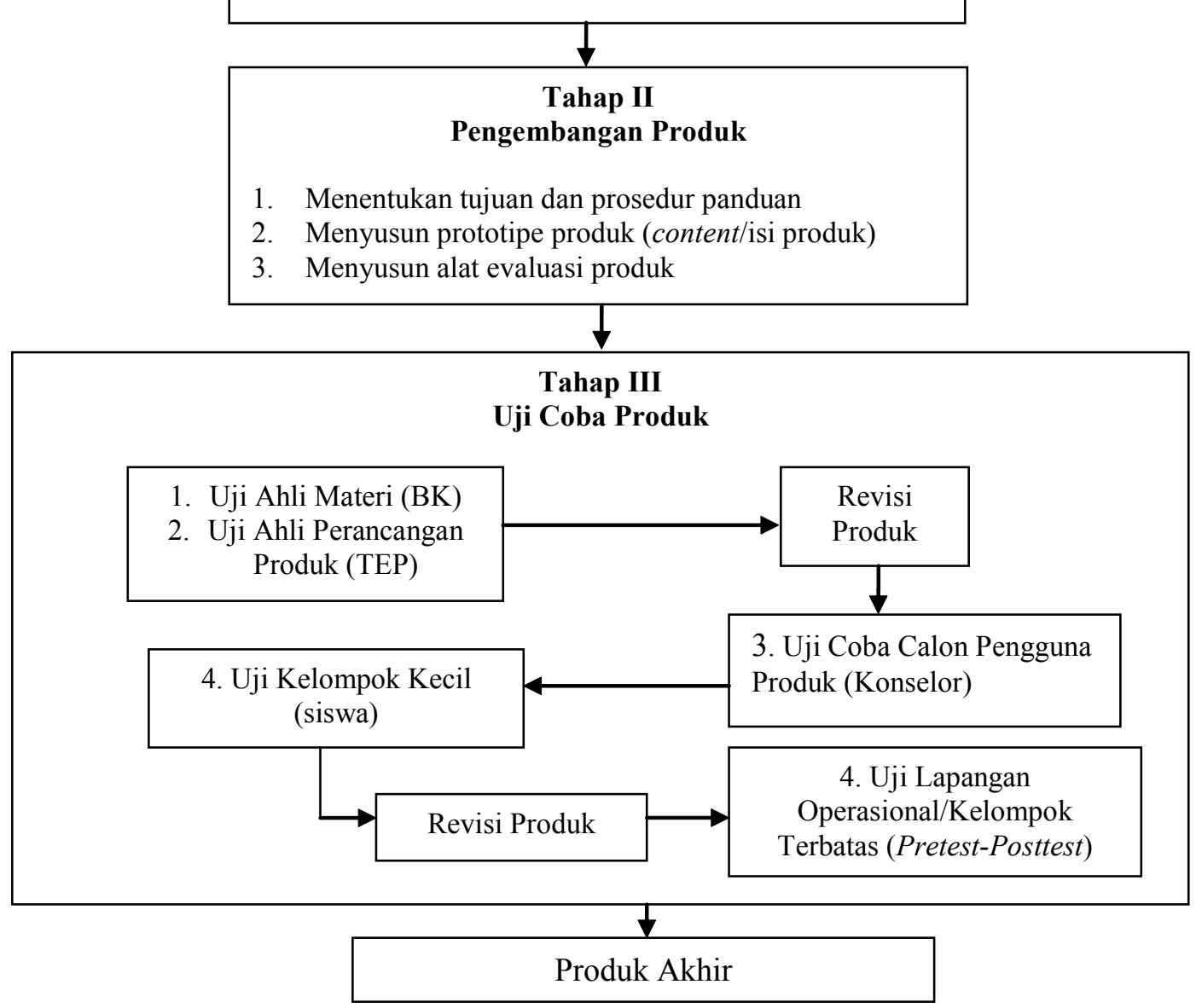

\section{Gambar 1 Prosedur Pengembangan Panduan}

\section{METODE}

Metode yang digunakan dalam melakukan penelitian dan pengembangan produk panduan pelatihan efikasi diri siswa SMP dalam hubungan pertemanan melalui strategi experiential learning mengadaptasi dari penelitian dan pengembangan dari Borg \& Gall (1983). Penelitian pengembangan ini dilakukan sampai tahap uji lapangan operasional/kelompok terbatas. Berikut gambaran tahapan yang dilaksanakan dalam pengembangan panduan.

Pelaksanaan penelitian pengembangan melalui tiga tahapan yaitu; (1) perencanaan pengembangan produk; (2) pengembangan produk; dan (3) uji coba produk. Tahap pertama dilakukan perencanaan pengembangan. Pada tahap ini dilakukan analisis terhadap adanya potensi masalah yang dialami oleh siswa, kemudian dilanjutkan dengan mengkaji literatur dan melakukan analisis kebutuhan. Tahap kedua adalah Penyusunan prototipe produk dimulai dari menentukan tujuan dan prosedur pengembangan produk, menyusun prototipe produk (content/isi materi), dan menyusun alat evaluasi produk. Setelah prototipe selesai dibuat tahap selanjutnya adalah melakukan uji coba produk.

Uji coba merupakan tahap terakhir dari pengembangan panduan pelatihan efikasi diri siswa SMP dalam hubungan pertemanan melalui strategi experiential learning. Kegiatan uji coba produk dilaksanakan dalam dua tahap yaitu, uji validasi kepada ahli materi dan ahli perancangan media yang kemudian dilanjutkan dengan melakukan uji coba produk kepada calon pengguna dan kelompok kecil. Tahap validasi uji ahli 
Rachmawati, Hidayah, Pengembangan Panduan Pelatihan... | 83

Tabel 1 Kriteria Penilaian Uji Coba Produk

\begin{tabular}{ll}
\hline \multicolumn{1}{c}{ Rentan Nilai } & \multicolumn{1}{c}{ Kriteria } \\
\hline $1,00-1,74$ & Tidak tepat/tidak berguna/tidak mudah/tidak menarik \\
$1,75-2,49$ & Kurang tepat/kurang berguna/kurang mudah/kurang menarik \\
$2,50-3,24$ & Tepat/berguna/mudah/menarik \\
$3,25-4,00$ & Sangat tepat/sangat berguna/sangat mudah/sangat menarik \\
\hline
\end{tabular}

dilakukan untuk untuk mengukur tingkat ketepatan, kegunaan, kemudahan, dan kemenarikan produk apakah sudah sesuai untuk diberikan kepada calon pengguna. Selain memberikan penilaian uji ahli juga memberikan saran dan kritik untuk memperbaiki dan menyempurnakan produk. Setelah produk dinyatakan valid, langkah berikutnya adalah melakukan uji coba pengguna produk oleh konselor dan dilanjutkan dengan uji kelompok kecil oleh siswa untuk melihat keberterimaan produk serta saran dan perbaikan produk.

Subjek uji coba produk terdiri dari subjek ahli dan calon pengguna produk. Subjek ahli terdiri dari ahli materi yang terdiri dari dosen Bimbingan dan Konseling dan ahli perancangan media yang terdiri dari dosen Teknologi Pendidikan dengan syarat pendidikan S2 dan kompeten dibidangnya. Calon pengguna produk adalah konselor SMP dengan kriteria yaitu berlatar belakang pendidikan minimal lulusan S1 jurusan Bimbingan dan Konseling dan pengalaman mengajar minimal 5 tahun. Sedangkan uji kelompok kecil dilakukan kepada 6 siswa SMP kelas VII.

Data yang diperoleh dari uji ahli dan uji calon pengguna (konselor) meliputi penilaian ketepatan, kegunaan, kemudahan dan kemenarikan terhadap prototipe panduan pelatihan efikasi diri dalam hubungan pertemanan strategi EL. Jenis data dalam pengembangan produk ini terdiri dari data kuantitatif dan data kualitatif. Data kuantitatif didapat dari skala penilaian yang diberikan pada ahli. Kriteria skala penilaian untuk ahli materi, perancangan produk dan calon pengguna produk adalah menggunakan 4 skala penilaian. Sedangkan data kualitatif didapat berdasarkan komentar, saran, dan masukan dari penilaian uji ahli dan pengguna. Untuk uji kelompok kecil (siswa) hanya memberikan penilaian secara kualitatif. Penilaian dari uji ahli dan calon pengguna tersebut sangat berguna dan diperlukan untuk kepentingan revisi berikutnya.

Pengumpulan data dalam pengembangan panduan ini menggunakan instrumen berupa angket. Angket berisi sejumlah pernyataan tertulis yang digunakan untuk memperoleh informasi dari ahli materi, ahli perancangan produk dan calon pengguna produk (2 konselor) mengenai keberterimaan produk (ketepatan, kegunaan, kemudahan, kemenarikan) media panduan yang dikembangkan. Sedangkan penilaian untuk uji kelompok kecil berisi pertanyaan dengan jawaban secara deskriptif.

Hasil penilaian ahli terkait ini terdiri dari data kuantitatif dan data kualitatif. Analisis data kualitatif yang berupa saran, masukan, dan tanggapan menggunakan analisis deskriptif kualitatif. Dengan begitu bisa diperoleh saran, masukan, dan tanggapan untuk merevisi produk panduan, sehingga bisa dijadikan sebagai media yang benar-benar tepat, berguna, mudah dan menarik untuk digunakan oleh pengguna. Data kuantitatif yang diperoleh dari para uji ahli dapat dianalisis dengan melihat rata-rata setiap aspek. Penilaian dibagi menjadi 4 kriteria yang disajikan dalam tabel 1 .

Setelah penilaian dari ahli dan pengguna produk didapatkan dan perbaikan produk dilakukan, berlanjut pada uji lapangan operasional/uji kelompok terbatas. Pada uji lapangan operasional dilakukan uji keefektifan pelatihan efikasi diri dalam hubungan pertemanan melalui strategi experiential learning dengan media panduan dengan melihat perbedaan hasil pretest dan posttest siswa. Pada uji lapangan operasional ini jumlah siswa terbatas 6 siswa kelas VII berdasarkan hasil pretest sedang dan rendah. Angket/instrumen pretestposttest yang digunakan berisikan butir pernyataan mengenai efikasi diri dalam hubungan pertemanan. Pemberian skor untuk pernyataan dalam instrumen mengacu pada model skala Likert dengan empat skala yaitu, sangat sesuai (skor 4), sesuai (skor 3), tidak sesuai (skor 2), sangat tidak sesuai (skor 1). Namun untuk butir pernyataan unfavorable skornya dibalik menjadi, sangat sesuai (skor 1), sesuai (skor 2), tidak sesuai (skor 3), sangat tidak sesuai (skor 4).

Data yang dianalisis pada uji lapangan operasional berupa data secara kualitatif dan kuantitatif. Data kualitatif berupa hasil observasi dan evaluasi selama kegiatan berlangsung. Penilaian ini dilakukan untuk mengukur tingkat keberhasilan pelatihan dengan menggunakan produk. Sedangkan data kuantitatif berupa hasil penghitungan skor pretest-posttest siswa sebelum dan sesudah diberikan perlakuan/treatment. Teknik 
analisis yang digunakan untuk melihat keefektifan penggunaan panduan pelatihan efikasi diri dalam hubungan pertemanan melalui strategi experiential learning adalah teknik analisis non-parametrik yaitu analisis Wilcoxon. Teknik analisis Wilcoxon dilakukan dengan cara menghitung taraf signifikan perbedaan rerata efikasi diri siswa dalam hubungan pertemanan sebelum dan sesudah diberikan perlakuan. Pengujian hipotesis

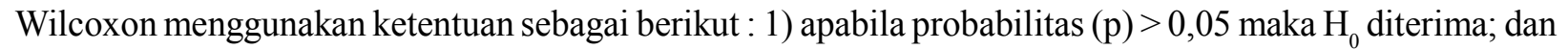
2) apabila probabilitas $(\mathrm{p})<0,05 \mathrm{maka}_{0}$ ditolak. Adapun hipotesis penelitian sebagai berikut :

$\mathrm{H}_{0}=$ panduan pelatihan efikasi diri dalam hubungan pertemanan melalui strategi EL tidak efektif meningkatkan efikasi siswa dalam hubungan pertemanan

$\mathrm{H}_{1}=$ panduan pelatihan efikasi diri dalam hubungan pertemanan melalui strategi EL efektif meningkatkan efikasi siswa dalam hubungan pertemanan

\section{HASIL}

Data hasil penilaian uji ahli digunakan sebagai dasar untuk merevisi produk pengembangan yang dihasilkan sebelum dilaksanakan uji coba calon pengguna produk. Setelah melakukan uji coba produk oleh ahli, prototipe produk kemudian diujicobakan kepada calon pengguna produk. Calon pengguna produk yaitu konselor. Uji coba dilaksanakan untuk memperoleh data berupa penilaian pada aspek keberterimaan produk, masukan, tanggapan, saran, dan kritik dari calon pengguna produk sebagai acuan dalam merevisi produk pengembangan yang dihasilkan sebelum dilakukan uji kelompok kecil. Uji kelompok kecil dilakukan untuk memperoleh data masukan, saran, dan kritik dari siswa sebagai acuan untuk merevisi akhir produk pengembangan yang dihasilkan. Sesuai dengan prosedur penelitian yang digunakan, produk diujikan untuk memperoleh penilaian pada aspek keberterimaan dan saran serta masukan sebagai pertimbangan perbaikan produk.

Berdasarkan hasil penilaian produk oleh ahli materi dari dosen Bimbingan dan Konseling, dapat diketahui bahwa nilai rerata pada aspek ketepatan adalah 3,60; aspek kegunaan adalah 4,00; aspek kemudahan adalah 2,77; aspek kemenarikan adalah 4,00 sehingga menunjukkan bahwa panduan memiliki kriteria sangat tepat, sangat berguna, mudah dan sangat menarik. Adanya saran dan masukan sebagai pertimbangan perbaikan yaitu langkah-langkah pelatihan secara keseluruhan pada panduan pegangan konselor lebih dijelaskan secara ringkas dan jelas, penambahan langkah kegiatan berupa evaluasi proses setiap topik pelatihan, serta pada evaluasinya tetap dilampirkan angket pretest-posttest oleh karena itu prototipe produk akan direvisi.

Berdasarkan hasil penilaian produk oleh ahli perancangan produk dari dosen Teknologi Pendidikan menunjukkan nilai rerata pada aspek ketepatan adalah 3,30; aspek kegunaan adalah 4,00; aspek kemudahan adalah 3,50; aspek kemenarikan adalah 3,16. Berdasarkan hasil penilaian, menunjukkan bahwa panduan memiliki kriteria sangat tepat, sangat berguna, sangat mudah dan menarik. Adanya saran dan masukan sebagai pertimbangan perbaikan yaitu lebih mengoptimalkan desain visual produk (jenis huruf, warna pada header footer) agar isi materi dan tampilan pendukung tidak saling mendominasi. Serta tampilan cover yang tidak perlu diberi tahun. Revisi/perbaikan produk dilakukan sebelum uji pada calon pengguna (konselor) dan kelompok kecil (siswa) dilakukan.

Berdasarkan hasil penilaian produk oleh calon pengguna dari konselor SMPN 8 Malang menunjukkan nilai rerata pada aspek ketepatan adalah 3,50; aspek kegunaan adalah 3,37; aspek kemudahan adalah 3,00; aspek kemenarikan adalah 3,50. Berdasarkan hasil penilaian produk oleh calon pengguna dari konselor SMPN 8 Malang menunjukkan bahwa panduan memiliki kriteria sangat tepat, sangat berguna, mudah dan sangat menarik. Adanya saran dan masukan sebagai pertimbangan perbaikan oleh konselor yaitu pada umumnya produk panduan sudah cukup baik namun sebaiknya gambar penunjang materi adalah gambargambar lokal atau gambar yang mewakili orang indonesia sendiri bukan orang luar. Adapun tanggapan, masukan, saran dan komentar yang disampaikan oleh siswa pada uji kelompok kecil terhadap produk panduan pelatihan efikasi diri dalam hubungan pertemanan melalui strategi experiential learning secara keseluruhan produk panduan sudah baik dan menarik namun perlu perbaikan pada proses penyampaian materi yang lebih santai dan ice breaking yang lebih bervariasi. 
Tabel 2 Hasil Skor Pretest-Posttest Siswa

\begin{tabular}{lccccc}
\hline \multirow{2}{*}{ Nama } & \multicolumn{5}{c}{ Nilai } \\
\cline { 2 - 5 } & Pretest & Klasifikasi & Posttest & Klasifikasi & \multirow{2}{*}{ Gcore } \\
\hline Auliya Tuhfatul & 81 & Sedang & 97 & Tinggi & 16 \\
Budi Jaya & 82 & Sedang & 107 & Tinggi & 25 \\
Akbar Aji Sakha & 78 & Sedang & 117 & Sangat Tinggi & 39 \\
Rafi Rendrahadi & 72 & Rendah & 127 & Sangat Tinggi & 55 \\
Alifia Manda & 80 & Sedang & 112 & Sangat Tinggi & 32 \\
Sabrina & 56 & Rendah & 100 & Tinggi & 44 \\
Rata-rata & & 74,83 & & 110 & 35,16 \\
\hline
\end{tabular}

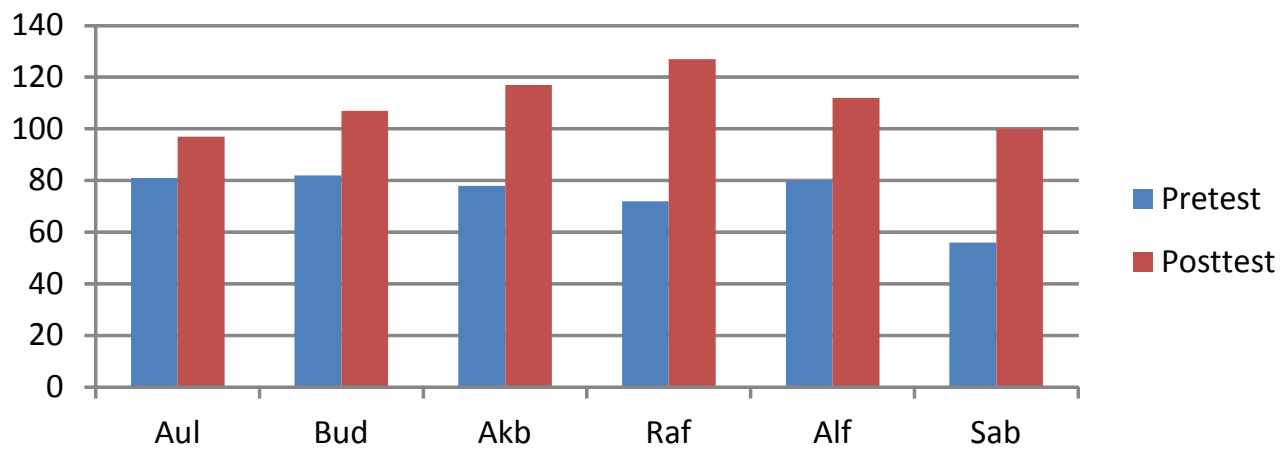

\section{Gambar 2 Diagram Batang Hasil Prettest-Posttest}

Penilaian uji lapangan operasional menggunakan data kuantitatif berupa penghitungan secara statistik untuk melihat keberbedaan hasil skor efikasi diri siswa sebelum dan sesudah diberi pelatihan menggunakan panduan sehingga dapat diketahui keefektifan produk yang telah dikembangkan. Adapun hasil perbedaan tersebut dapat dilihat pada tabel 2 dan gambar 2

Gambar 2 merupakan data hasil pretest-posttest uji lapangan operasional pada 6 siswa. Dari diagram tersebut dapat diketahui peningkatan efikasi diri siswa dalam hubungan pertemanan sebelum dan sesudah diberikan pelatihan dengan menggunakan panduan. Batang skor pretest dengan warna biru dan batang skor posttest dengan warna merah.

Selain itu penilaian hasil pretest-posttest juga dianalisis secara keseluruhan yaitu dengan uji wilcoxon pada SPSS 20.00. Dari hasil analisis hasil pretest-posttest efikasi diri dalam hubungan pertemanan, terdapat hasil yang signifikan pada hasil pretest dan posttest siswa. Berdasarkan output, didapatkan hasil nilai $\mathrm{Z}$ sebesar -2,201 ${ }^{\mathrm{b}}$ dan nilai Asymp.sig. (2-tailed) menunjukkan nilai sebesar 0,028, dimana 0,028<0,05 maka $\mathrm{H}_{0}$ ditolak dan $\mathrm{H}_{1}$ diterima, sehingga hasil pretest-posttest dari pengembangan panduan dinyatakan memenuhi indikator keefektifan, maka pengembangan panduan pelatihan efikasi diri dalam hubungan pertemanan melalui strategi EL terbukti efektif dalam meningkatkan efikasi diri siswa di dalam hubungan pertemanan sebaya.

Penilaian keberhasilan pelatihan kepada siswa tidak hanya pada penilaian secara hasil melalui uji pretestposttest dengan menggunakan skala efikasi diri dalam hubungan pertemanan saja, namun dengan adanya rubrik evaluasi, sehingga konselor mampu mengamati perkembangan dan perubahan perilaku siswa. Adapun hasil pengamatan selama proses kegiatan pelatihan berlangsung menunjukkan beberapa perilaku siswa yang semakin menunjukkan keyakinan diri, seperti siswa mulai aktif dalam mengikuti kegiatan, siswa memulai perkenalan dan berinteraksi dengan teman terlebih dahulu, yang semula diam menjadi mau berbicara dan berbaur dengan teman yang lain, mulai yakin untuk mampu menyelesaikan konflik dengan teman dan mampu menumbuhkan motivasi di dalam dirinya. Penilaian tersebut juga menjadi indikator keberhasilan dari pemberian pelatihan efikasi diri dalam hubungan pertemanan melalui strategi EL yang dikembangkan dengan sebuah panduan. 


\section{BAHASAN}

Dilihat dari hasil uji keberterimaan oleh ahli, calon pengguna (konselor) serta siswa dalam uji kelompok kecil, Pengembangan panduan pelatihan efikasi diri siswa SMP dalam hubungan pertemanan melalui strategi experiential learning dinilai layak untuk digunakan

Pengembangan produk ini bertujuan untuk menghasilkan suatu panduan yang dapat membantu siswa memperoleh informasi terkait dengan keyakinan diri/efikasi diri dan mengembangkannya di dalam proses berhubungan dengan teman sebaya. Disamping itu hasil produk pengembangan ini dapat digunakan oleh konselor sebagai salah satu alternatif media dalam pemberian layanan bimbingan pribadi-sosial kepada siswa mengenai efikasi diri di dalam hubungan pertemanan.

Pengembangan panduan pelatihan efikasi diri dalam hubungan pertemanan melalui strategi experiential learning didasarkan pada kebutuhan siswa akan layanan Bimbingan dan Konseling yang menyenangkan, memandirikan, dan tidak monoton dengan memakai cara yang sering digunakan pada umumnya. Melalui pengembangan panduan ini, siswa dapat memperoleh informasi tentang efikasi diri di dalam hubungan pertemanan sekaligus bisa melatih efikasi diri/keyakinan dirinya melalui aktivitas-aktivitas latihan yang terdapat di dalam panduan. Adapun dalam pelaksanaan pelatihannya dibutuhkan suatu media yang dapat membantu konselor dalam memberikan materi pelatihan sekaligus membantu siswa dalam memberikan pemahaman materi secara lebih. Media yang dikembangkan berupa bahan ajar berbasis buku cetakan yang berisi materi, langkah kegiatan, serta evaluasi. Di dalamnya terdiri dari desain sampul yang menarik, penyajian materi yang disesuaikan dengan aspek-aspek efikasi diri yang akan dilatihkan dan keadaan yang dialami oleh siswa, disertai dengan lembar refleksi diri, dilengkapi dengan ilustrasi dan halaman kata-kata motivasi, pemilihan warna dan jenis huruf dipikirkan secara matang agar tepat dan menarik untuk dibaca.

Produk panduan terdiri dari panduan untuk konselor dan panduan untuk siswa. Panduan untuk konselor bertujuan memberikan gambaran kepada konselor tentang tata cara penggunaan buku, hal apa saja yang perlu dipersiapkan oleh konselor, dan kegiatan yang perlu dilakukan oleh konselor, sehingga konselor lebih mudah melaksanakan bimbingan kepada siswa. Sedangkan panduan untuk siswa yaitu sebagai sarana penyampaian informasi kepada siswa tentang efikasi diri di dalam hubungan pertemanan dan bagaimana melatihnya. Dalam pelaksanaannya terdapat serangkaian aktivitas yang dilakukan oleh siswa, untuk itu diperlukan pengawasan dan bimbingan oleh konselor.

Pada panduan terdapat topik-topik yang dilatihkan dimana topik tersebut merupakan aspek-aspek di dalam efikasi diri (Bandura, 1997) dan dihubungkan serta dikembangkan ke dalam proses hubungan pertemanan. Topik-topik tersebut yaitu; (1) keyakinan diri dalam menghadapi situasi tidak menentu, dengan topik "aku mampu berinteraksi dengan baik dan menyenangkan"; (2) keyakinan diri dalam menyelesaikan hambatan, dengan topik "tangguh menyelesaikan konflik, why not?"; (3) keyakinan diri dalam menetapkan tujuan, dengan topik "tak peduli kata orang, aku pun mampu menjadi mawar yang disukai kupu-kupu"; dan (4) menumbuhkan motivasi, dengan topik "aku pasti bisa".

Masing-masing topik dilatihkan dengan berbagai aktivitas menyenangkan yang melibatkan siswa aktif secara langsung di dalamnya, seperti aktivitas permainan peran (sosiodrama), menonton video, refleksi diri dan diskusi kasus. Dalam setiap topik yang disajikan materi telah disesuaikan dengan keadaan sehari-hari siswa, materi berisi menunjukkan tentang permasalahan yang sering dialami oleh siswa dalam hubungan pertemanan sebayanya beserta dengan apa yang seharusnya siswa lakukan untuk membuat siswa mampu meyakini potensi di dalam dirinya dan mampu untuk dikembangkannya didalam hubungan pertemanan tersebut.

Dalam aktivitas permainan peran (sosiodrama), merupakan dramatisasi dari persoalan-persoalan yang dapat timbul dalam pergaulan dengan orang lain dan tingkat konflik-konflik yang dialami dalam pergaulan sosial melalui permainan peran. Peranan yang dimaksudkan agar individu yang bersangkutan dapat memperoleh pengertian yang lebih baik tentang dirinya dan hubungan sosialnya dengan orang lain, dapat menemukan konsep dirinya dan orang lain, menyatakan kebutuhan-kebutuhan dan menyatakan reaksinya terhadap tekanan-tekanan sosial terhadap dirinya (Romlah, 2013). Sosiodrama disini dimaksudkan untuk menciptakan konsep-konsep yang nyata dalam diri siswa mengenai efikasi dalam pertemanan. Selain melalui sosiodrama, siswa diajak untuk membagi pengalaman baru berupa situasi motivasional yang disajikan dalam penayangan video dan cerita, baik berdasarkan pengalamaan pribadi/pengalamaan orang lain.

Melakukan refleksi diri setelah membaca materi, melakukan permainan peran dan menonton video 
yang ada pada setiap topik. Siswa bisa melakukan refleksi terhadap dirinya terkait dengan permasalahan di dalam proses pertemanan dan keyakinannya menghadapi situasi-situasi itu. Setelah melakukan refleksi siswa bisa tahu keyakinan dan perilaku apa yang harus ditingkatkan, melakukan diskusi kasus bersama siswa lain, sehingga lebih ditekankan pada kegiatan menyamakan ide atau pendapat siswa terhadap suatu topik yang disajikan, bagaimana mereka melihat fenomena yang ada. Dalam pelatihan ini, siswa akan dihadapkan pada suatu cerita/kasus yang berhubungan dengan topik dalam materi pelatihan efikasi diri dalam hubungan pertemanan. Dan diakhiri dengan evaluaasi untuk mengukur seberapa tinggi tingkat penerimaan siswa. Evaluasi ini bertujuan agar siswa benar-benar memahami apa yang telah mereka peroleh dan lebih memantapkan siswa bahwa mereka memiliki pemahaman pada aspek tersebut (berhubungan dengan topik), sehingga mereka akan termotivasi untuk berbuat atau melakukan sesuatu yang sebelumnya mereka anggap tidak mampu mereka lakukan atau raih serta menerapkannya di dalam kehidupan sehari-hari.

Serangkaian aktivitas tersebut merupakan aktivitas pengejawantahan dari tahapan siklus experiential learning oleh David Kolb (1984). Tahapan siklus Kolb (1984) yaitu pengalaman konkrit (concrete experience), observasi reflektif (reflective observation), konseptualisasi abstrak (abstract conceptualization) dan ekperimentasi aktif (active experimentation). Dengan strategi experiential learning, siswa mampu menginternalisasi pemahaman serta keterampilan yang diperoleh selama pelatihan berdasarkan pengalaman belajar yang diperoleh dan mampu mengembangkan dan meningkatkan efikasi dirinya di dalam hubungan pertemanan sebaya.

Dari beberapa penelitian yang telah dilakukan yang berkaitan dengan model experiential learning, seperti penelitian yang telah dilakukan oleh, Sayekti (2012), Purwaningrum (2013), Azmi (2014) dan Utami (2015), dapat disimpulkan bahwa model EL dapat digunakan sebagai strategi untuk meningkatkan perilakuperilaku dan keyakinan positif pada individu atau siswa. Berdasarkan hasil beberapa penelitian yang telah dilakukan sebelumnya oleh Sayekti, Purwaningrum, Azmi dan Utami serta hasil penelitian pengembangan yang dilakukan oleh peneliti berkaitan dengan panduan pelatihan efikasi diri dalam hubungan pertemanan melalui strategi EL, bahwa model EL merupakan strategi yang efektif untuk digunakan dalam meningkatkan efikasi diri siswa di dalam hubungan pertemanan.

Sejalan dengan itu, panduan ini juga terbukti memenuhi kriteria produk yang dapat dikembangkan. Borg \& Gall (1983:776) menyatakan beberapa kriteria suatu produk yang terseleksi atau dapat dikembangkan yaitu; (1) apakah tujuan produk yang dikembangkan memenuhi kebutuhan penting dalam pendidikan; (2) apakah bagian dari seni mampu menunjang pengembangan produk yang baik atau diinginkan; (3) apakah personel yang bersangkutan dengan pengembangan produk harus memiliki keterampilan, pengetahuan dan pengalaman di dalamnya; dan (4) bisakah produk dikembangkan dalam waktu yang tentukan. Berdasarkan kriteria tersebut, panduan pelatihan efikasi diri dalam hubungan pertemanan melalui strategi experiential learning bagi siswa SMP telah menjawab dan memenuhinya.

Panduan ini disusun atas hasil kebutuhan (need assesment) siswa yang peneliti lakukan di SMPN 8 Malang. Sedangkan dari hasil wawancara yang dilakukan dengan konselor juga didapatkan hasil bahwa siswa sangat membutuhkan informasi dan pelatihan tentang efikasi diri di dalam hubungan pertemanan. Berkaitan dengan banyaknya permasalahan siswa pada aspek sosial, masih banyak siswa yang minder dan tidak yakin di dalam melakukan hubungan sosial atau hubungan pertemanan sebaya. Disamping itu, dalam pengembangan produk aspek kemenarikan dan ketepatan senantiasa berkaitan, termasuk di dalamnya yaitu aspek seni. Desain gambar, tulisan, sampul dan beberapa desain visual lainnya sangat mempengaruhi kemenarikan oleh para calon penggguna, khususnya siswa. Panduan ini terbukti memenuhi aspek kemenarikan dan ketepatan dalam desain visual, baik cover maupun isi. Baik siswa maupun konselor menyatakan tampilan panduan secara umum baik dan menarik untuk digunakan.

Dalam pengembangan panduan pelatihan efikasi diri dalam hubungan pertemanan melalui strategi experiential learning bagi siswa SMP, membutuhkan kerjasama dengan personel yang ahli/expert di bidangnya, seperti ahli materi dari dosen Bimbingan dan Konseling, ahli perancangan produk dari dosen Teknologi Pendidikan dan calon pengguna dari konselor yang telah berpengalaman dalam mengajar untuk menguji produk yang dikembangkan, sehingga mampu diterima secara teoritik dan praktik. Dan pengembangan panduan ini menjawab kriteria yang terakhir, yaitu pengembangan panduan dalam waktu yang ditentukan. Dalam pengembangannya, waktu yang dibutuhkan peneliti adalah 6 bulan. Suatu produk dapat dikembangkan 
dalam waktu yang fleksibel atau tidak ditentukan, namun tidak menutup kemungkinan produk selesai dalam waktu yang ditentukan tetapi sudah cukup memenuhi aspek keberterimaan oleh uji ahli dan calon pengguna.

Selain adanya kelebihan, terdapat beberapa kelemahan pada penelitian dan pengembangan ini, diantaranya adalah; (1) penilaian produk oleh calon pengguna (siswa) terbatas pada lembar saran tidak seperti penilaian oleh uji ahli dan uji pengguna (konselor) yang berupa skala keberterimaan, sehingga hasil penilaian oleh siswa bersifat kasar; (2) secara tampilan dan content panduan, terdapat beberapa bagian yang perlu perbaikan seperti kelengkapan instrumen evaluasi, visualisasi tampilan, gambar dan langkahlangkah pelatihan, sehingga membuat penilaian pada aspek tersebut kurang sempurna; dan (3) berdasarkan strategi experiential learning dimana pembelajaran berdasarkan pengalaman maka aktivitas pelatihan juga dibuat bervariasi seperti sosiodrama, menonton video, refleksi diri dan diskusi kasus. Dengan banyaknya aktivitas dan dilakukan berulang-ulang beberapa siswa terlihat bosan, sehingga dibutuhkan ketrampilan lebih untuk dapat memotivasi siswa dan mencairkan suasana kebosanan siswa.

\section{SIMPULAN DAN SARAN}

Berdasarkan hasil analisis dan data revisi, pengembangan panduan pelatihan efikasi diri dalam hubungan pertemanan melalui strategi experiential learning memenuhi kriteria keberterimaan secara teoritik dan praktik dengan baik oleh uji ahli dan calon pengguna produk. Disamping itu, pengembangan produk panduan pelatihan efikasi diri dalam hubungan pertemanan melalui strategi experiential learning terbukti efektif meningkatkan keyakinan diri/efikasi diri siswa di dalam hubungan pertemanan sebaya setelah melalui uji statistik wilcoxon. Melihat dari kriteria keberterimaan yang diperoleh dan keefektifan yang terbukti dapat disimpulkan bahwa pengembangan panduan pelatihan efikasi diri dalam hubungan pertemanan melalui strategi experiential learning layak digunakan sebagai salah satu media dalam pemberian layanan bimbinagn pribadisosial oleh konselor kepada siswa khususnya dalam meningkatkan efikasi diri siswa dalam hubungan pertemanan.

Berdasarkan penelitian yang telah dilaksanakan terdapat beberapa saran untuk dijadikan bahan pertimbangan dan perhatian oleh beberapa pihak: (1)saran bagi konselor yaitu konselor dapat menggunakan panduan sebagai media dalam memberikan layanan bimbingan pribadi-sosial kepada siswa khususnya untuk meningkatkan efikasi diri dalam hubungan pertemanan (2)peneliti selanjutnya, format penilaian oleh ahli dan calon pengguna dapat diperhatikan lebih rinci karena penilaian oleh masing-masing ahli dan pengguna tidaklah sama. Disamping itu, tampilan serta content panduan juga perlu diperhatikan secara lebih dan rinci, sehingga penilaian yang didapatkan sempurna dan tidak banyak perbaikan.

\section{DAFTAR RUJUKAN}

Azmi, K. R. 2014. Pengembangan Panduan Pelatihan Mind Skills Dalam Konseling Dengan Model Experiential Learning untuk Mahasiswa Bimbingan dan Konseling Universitas Negeri Malang. Skripsi. Tidak diterbitkan. Malang: Universitas Negeri Malang.

Bandura, A. 1997. Self-Efficacy, The Exercise of Control. New York: Freeman and Company.

Borg, W. R. \& D. Gall. 1983. Educational Research. New York: Longman Inc.

Kolb, D. 1984. Experiential Learning: Experience as The Source of Learning and Development. New Jersey: Prentince Hall, Inc.

Purwaningrum, R. Internalisasi Mindskiils Mahasiswa BK Melalui Experiential Learning. Thesis. Tidak diterbitkan. Malang: Program Pasca Sarjana UM.

Romlah, T. 2006. Teori dan Praktik Bimbingan Kelompok. Malang: Universitas Negeri Malang.

Santoso, D. B. 2009. Dasar-dasar Bimbingan dan Konseling: Malang: Tanpa penerbit.

Satici,S.A., Kayis,A.R \& Akin, A (2013). Investigating the Predictive Role of Social Self-Efficacy on Authenticity in Turkish University Students. Europe's Journal of Psychology, 2013, Vol. 9(3), 572 580, doi:10.5964/ejop.v9i3.579. 
Sayekti, R. W. 2012. Pengembangan Paket Pelatihan Efikasi Diri Untuk Meningkatkan Motivasi Berprestasi Siswa Sekolah Menengah Atas. Skripsi. Tidak diterbitkan. Malang: Universitas Negeri Malang.

Utami, H. B. 2015. Pengembangan Panduan Pelatihan Coping Self Talk Dengan Model Experiential Learning bagi Siswa SMK Jurusan Keperawatan. Skripsi. Tidak diterbitkan. Malang: Universitas Negeri Malang. 